\title{
"I Wander Through, the Alleys Skein-drawn by the Sound:" Moderate Reclusion in Vikram Seth's Poems of Suzhou Classical Gardens
}

\author{
Zhi Huang \\ College of Foreign Languages, Soochow University, China
}

Copyright (C) 2016 by authors, all rights reserved. Authors agree that this article remains permanently open access under the terms of the Creative Commons Attribution License 4.0 International License

\begin{abstract}
I argue that it is the very "moderate reclusion" accurately represented by the central components of Suzhou classical gardens that Vikram Seth, himself often referred to as a "reclusive writer", feels at home with and discourses at length on in his poems. To put it at its simplest, Seth, by portraying the people and objects of classical gardens in Suzhou, demonstrates the garden owners' as well as his own high hopes and aspirations for moderate reclusion.
\end{abstract}

Keywords Vikram Seth, Poems, Suzhou Classical Gardens, Moderate Reclusion

\section{Introduction}

From 1980 to 1982, Vikram Seth, then a doctoral student in Chinese economics at Stanford, visited Nanjing University and did his research in some towns on the Yangtse. The field researches, if boring, brought him to the city of Suzhou, where he became so completely infatuated with Suzhou classical gardens that he authored a succession of poems on them, and even named his 1985 poetry after Humble Administrator's Garden, one of the four most reputed classical gardens in Suzhou.

These poems, delightfully exotic and intricately crafted, have generated a constant stream of scholarly criticism. According to Rohini Mokashi-Punekar [1], the poems of Suzhou classical gardens bear the stamp of "anti-romanticism." She continues: "In Seth's poetry the predominant trend is an anti-romantic attitude towards the world. Though his poems reveal how moved he is by nature and her beauty, it is the natural scene that is on display in his several nature poems, and not his own subjective self" (20). In other words, deprived of the author's inner workings of mind, these poems may be relegated to "the natural scene...on display" only. Inspiring as it is, Mokashi-Punekar's argument merely scratches the surface of the nature writing in Seth's poems; by no means has it delved deeper into his mentality while he was composing them.

Seemita Mohanty [2], on the other hand, concentrates her gaze on the "feelings of rest and relaxation" inspired, in all probability, by "the traditional contemplative Chinese conditions, where 'temples' abound" (54). Not only does Mohanty's critical inquiry unravel the mystery of Seth's artistic mentality, but it, with penetrating insight, associates the poet's "feelings of rest and relaxation" with the "Chinese conditions." However, Mohanty's critical observations are so outrageously obscure that they are reduced to hasty generalizations and unsupported claims.

I argue that it is the very "moderate reclusion" accurately represented by the central components of Suzhou classical gardens that Vikram Seth, himself often referred to as a "reclusive writer" i, feels at home with and discourses at length on in his poems. To put it at its simplest, Seth, by portraying the people and objects of classical gardens in Suzhou, demonstrates the garden owners' as well as his own high hopes and aspirations for moderate reclusion.

It is widely acknowledged that the classical gardens in Suzhou are a product of the tradition of reclusion in China. Ke Jicheng [3], for instance, maintains:

Surviving thousands of years of construction and selection by scholar-bureaucrats, the recluse tradition in China has already sunk deep into our minds. Residence-gardens as well as scholar's gardens by nature, Suzhou classical gardens can generally be termed earthly gardens, which are definitely in the recluse tradition. Apart from Lion Grove, all the Suzhou gardens, including Gentle Waves Pavilion, Master-of-Nets Garden, Humble Administrator's Garden, Tarrying Garden, Mountain Villa with Embracing Beauty, Garden of Couple's Retreat, Garden of Cultivation, were constructed with utmost care by the highly cultured noble lords in seclusion. Instead of following the example of Tao Yuanming, who subscribed wholeheartedly to the theory that 'While picking asters 'neath the Eastern fence, My gaze 
upon the Southern mountain rests,' the noble lords were probably afraid of the deserted forest and all wound up building their lands of warmth in the city of Suzhou, where the court and the marketplace were readily accessible (translation mine) (50)

To complicate matters further, what Suzhou classical gardens represent is the "moderate reclusion" (Ke 50) in China's tradition of reclusion-situated in downtown Suzhou, the gardens combined both convenience and quietness, whose hermit-owners, still mindful of worldly concerns, seemed joyfully absorbed in making sightseeing tours out of town and entertaining friends at home. The owners, therefore, were bothered neither by the annoying turbulence of "great reclusion," nor by the aching loneliness of "petty reclusion" ii . The Humble Administrator's Garden that Seth visited and wrote about is a good example. In the early 1500s, Wang Xianchen, a historian and censor with frustrated ambitions in politics, returned to Suzhou and built this garden on the site of a dilapidated Buddhist temple in the downtown area. Derived from a poem "Watering the garden and tilling the land for three meals a day, the administrative work of a man of humble origins"(translation mine)(Wang [4] 10), the garden's name, along with the garden's location, shows what Wang sought for was a life of both quietness and convenience.

The garden owners' relentless pursuit of moderate reclusion is also Seth's. A closer examination of Seth's academic years at Stanford reveals that his life then was despairingly falling apart. This is due, in part, to his lack of interest in what he was learning at Stanford. "The subject was dry, mathematically unrealistic and intellectually unchallenging" (26), Seth [5] later remarked. A man of a retiring and seclusive disposition, he ended up skipping classes, immersing himself in Chinese language and culture, and finally leaving for Nanjing, where Seth [6] preferred to "bicycle from the university...gain some sense of quiet: the wooded paths, with acorns and chestnuts strewn across the ground, the layers of leaf mound, the sunlight spraying through the branches of the wutong trees" (19), while his worldly concerns still remained in him-his $\mathrm{PhD}$ research programs, family, etc.

In "A Little Night Music," the opening poem of The Humble Administrator's Garden, Seth delineates his initial encounter with the city of Suzhou, conveying already his passionate yearning for moderate reclusion. Seth [7] chants:

White walls. Moonlight. I wander through

The alleys skein-drawn by the sound

Of someone playing the erhu.

A courtyard; two chairs on the ground.

As if he knew I'd come tonight

He gestures, only half-surprised.

...

He pauses, tunes, and plays again

An hour beneath the wutong trees

For self and stranger, as if all men

Were brothers within the enclosing seas. (9)
Downtown Suzhou notwithstanding, "he" remains aloof in his detachment, deeply engrossed, at the same time, in entertaining friends. So greatly fascinated is Seth by this lifestyle that he makes the speaker "wander through, The alleys skein-drawn by the sound." Metaphorical as they are, the lines sketch out Seth's strong predilection for and his determined attempt at moderate reclusion, which is expanded upon and reinforced in the following poems of Suzhou classical gardens.

\section{Retirement into Seclusion}

Mention has to be made, above everything else, of Wang Wei, one of the Tang dynasty Chinese poets immensely influential in Seth's poetry writing ${ }^{\text {iii }}$. His political ambitions unfulfilled, Wang is generally believed to have led a life of frequent seclusion in the Chinese tradition of reclusion ${ }^{\text {iv }}$. A summary of Wang's poetics Seth [8] provides in Three Chinese Poets can shed considerable light on his real empathy for this ancient Chinese master: "Wang Wei's typical mood is that of aloneness, quiet, a retreat into nature and Buddhism. What one associates with him are running water, evening and dawn, bamboo..." (xvi). Like Wang's, what one can associate with Seth's poems of classical gardens are flowers, bushes, ponds, fish, etc, which are an fundamental component of the gardens' landscaping. Heartily tired of his own intellectual pursuits, Seth, by the same token, felt a desperate craving for "aloneness, quiet, a retreat into nature," which finds its full articulation in his poetic representation of the landscaping par excellence. In this light, Seth's nature writing and the underlining mentality are typically Wang's.

Not only can Seth, via the flowers, bushes, ponds and fish of classical gardens, voice his wishes to retire into seclusion, but represent and underscore simultaneously the tradition of reclusion Suzhou classical gardens communicate. The charm of Suzhou classical gardens resides predominantly in their very landscaping, which equips them with lush vegetation, rock hills, ponds, goldfish, etc. Hence a quasi-suburban enclave in downtown Suzhou. At the heart of this landscaping design is, as opposed to luxurious urban living, garden owners' love of rustic pleasures, and more significantly, detachment from worldly concerns it epitomizes:

The classical gardens south of the Yangtse used to serve as backyards for the government officials and the rich merchants in seclusion. Designed for leisure, the gardens always exhibit a natural charm of mountains and waters with their artful arrangement of rock hills, ponds, groves, stones, trails, etc. Small-scale as they are, delicately constructed gardens of Suzhou enable people to "have the pure enjoyment of wilderness without leaving the city" (translation mine)( Suzhou Classical Garden Administration [9] 15).

The following is an analysis of the flora and fauna in the 
poems of classical gardens, whereby Seth's as well as the garden owners' craving for "aloneness, quiet, a retreat into nature" will come to light.

To start with, the plants Seth gives high priority to in his poetic representations are the most commonly seen in those classical gardens. In "The Master-of-Nets Garden," he records:

\section{Magnolia petals fall, pale, fragrant, brown, \\ Resting on moss within a square of white; \\ Courtyard of quietness, of intimate stone}

Three moons - of water, mirror, sky — define

Pine and old cypress struggling against the stars,

And jasmine and gardenia combine

Their scent with that of closed magnolias. (Seth [7] 10)

Delightfully depicted with utmost detail, "magnolia," "moss," "pine," "cypress" and "jasmine," together with their colors and scent, build up a plant ecology in the wilderness.

This poetic ecology Seth constructs, as a matter of fact, roughly corresponds with the garden owners' original intention. In their attempt to emulate the barren wilderness, garden owners usually grew a wide variety of garden plants, which, together with stones and insects, bear much resemblance to their counterparts in the suburbs. "In Suzhou classical gardens, the landscaping normally follows the style of nature, i.e. emulating nature...Deciduous trees and evergreens are planted together in large numbers, creating an environment of groves and mountains with their mixed crowns, leaves, colors, etc"(translation mine) (Suzhou Classical Garden Administration [9] 32), Suzhou Classical Garden Administration describes. It's crystal clear that garden plants could enable the owners to retreat into an emulated natural environment they always desired. Likewise, implicit within Seth's master strokes is his genuine love of an undisturbed and nature-friendly life in the wilderness, which can be clearly discerned in such emotional expressions as "courtyard of quietness" and "intimate stone."

Besides, Seth lends a supreme sophistication to the garden plants that come into focus. At the center is the magnolia, a plant that both inaugurates and concludes the poem, and symbolizes particular virtues in Chinese culture: "The magnolia is also sometimes depicted with another plant known as fragrant thoroughwort...to give the meaning 'pure and noble"'(Welch [10] 31). This culturally specific learning is echoed by Seth's choice of words in describing the magnolia- "pale, fragrant, brown" and "white." Therefore, not only does Seth's accentuation of magnolias demonstrate his love of this culture-loaded plant, but convey his "purity and nobility", i.e. the aloofness form worldly and material pursuits.

Aside from garden plants, what also come alive in Seth's poems of Suzhou classical gardens are living creatures. In "The Humble Administrator's Garden" and "The Gentle Waves Pavilion," for example, he describes:

A plump gold carp nudges a lily pad

And shakes the raindrops off like mercury,
And throws a dumpling to a passing fish. (Seth [7] 11)

A pool as green as pea-soup. Four sleek fish,

Red as pimentos, push through bubbly scum.

A vagrant sparrow from a rocky niche

Looks critically on... (Seth [7] 13)

If the garden plants paint a static picture of the uncharted wilderness Seth desires, what he endeavors to produce in the "carp," "fish" and "sparrow" is a dynamic one. "Nudg(ing)," "shak(ing)," "passing," "push(ing) through" and "look(ing)," the lovely creatures, like their floral counterparts, help build up a live animal ecology.

Similarly, this animal ecology can find significant echo in what the garden owners intended to establish- - wandering fish...can all breathe new life into the garden's landscaping"(translation mine) (Suzhou Classical Garden Administration [9] 12). It's an admitted fact that the "wandering fish" lend even greater vividness to the emulated environment the owners wished to withdraw to, laying bare, once again, their continuing quest for an ideal haven of peace. By the same token, in the creatures' gentle and graceful "nudge", "shake" and "push" resides Seth's undying love of an environment that is fuller of life, a vibrant garden of Eden where he can retire into oblivion.

The lovely creatures, among which fish and carp are of paramount importance, are well endowed with Seth's continuing preoccupations. In addition to plenitude and abundance, fish, as a cultural symbol in China, remains in close association with the tradition of reclusion:

Fishing was also understood to be an activity of those heroes, scholars, misunderstood philosophers, poets, and other eccentrics who had chosen to leave the world of the city and politics. The Daoist philosopher Zhuāngzi (庄子) declared "to his friend that he knows the joy of fish. Ever since, the happiest attributed to fish has come to symbolize an ideal, secluded and peaceful life" (Welch [10] 96).

This is, likewise, reinforced by Seth when he confers upon the "plump gold carp" of "The Humble Administrator's Garden" considerable freedom of movement and action - "nudge," "shake" and "pass." Also, the carp's unrestrained play with the "lily pad" and "raindrops" gives specificity to a sense of withdrawal Seth dedicatedly strives for.

All the culture-loaded flora and fauna, be they garden plants or creatures, are suffused with the owners' genuine desire to retreat into a suburban atmosphere of tranquility. Having devoted much narrative energy to these subject matters, Seth, with the same mindset, brings to the fore his underlying craving for a life of reclusion and solitude. The imaginary moments he creates in "The Humble Administrator's Garden" can perhaps summarize this mentality:

The Humble Administrator admires a bee

Poised on a lotus, walks through the bamboo wood, 
Strips half a dozen loquats off a tree

And looks about and sees that it is good.

He leans against a willow with a dish

And throws a dumpling to a passing fish. (Seth [7] 11)

\section{Worldly Concerns}

Like Wang Wei who, though in seclusion, took office once in a while, Vikram Seth is not a strong proponent of complete reclusion and solitude whatsoever-he attaches equal importance to the joy of having company and blending into society, hence moderate reclusion. In the travelogue From Heaven Lake, he recalls, for instance: "For his last supper in Nanjing I have bought a bottle of Californian red wine at the Friendship Store...it all seems worthwhile as we drink the lovely well-analysed liquid. Nostalgia for the Golden State, and particularly San Francisco, pours over me in pacific waves" (Seth [6] 34).

This sociable side of reclusion finds its way into the classical gardens Seth visited. Ke Jicheng [3] maintains:

Obsessed with sentimental verse writing and binge drinking, the garden owners still remembered the ethics, morals and classics of Confucianism, and strived to gain both fame and wealth. Though they modeled themselves on Meng Haoran, it was his "worldly renowned literary talent and freewheeling life," not his grinding poverty that they desired (translation mine) (50).

In other words, the garden owners, though deeply envious of a sequestered life, could not entirely disentangle themselves from worldly concerns and pleasures. The gardens' location in downtown Suzhou betrayed their hidden earthly desires.

It can be argued that this side of Suzhou classical gardens becomes a vehicle of exposure and revelation for Seth's own worldliness. A careful perusal of the poems of classical gardens shows that, in addition to various garden plants and living creatures, his worldly pursuits are highly valorized, and that some verses are rhythmically throbbing with such worldly feelings as excitement, worries, wishes, and the like.

In these serially connected poems, delight is arguably the most obvious worldly pursuit that Seth associates with Suzhou classical gardens. "The North Temple Tower" offers a representative example:

On the North Temple Tower, from the fifth floor

I pull fierce faces at two boys below.

One gasps, and tells the other what he saw:

A waibin in the throes of vertigo.

They look again. I spread my arms and grunt.

Sudden delight: they point upwards and scowl.

One imitates a baby elephant.

The other glares and totters like an owl.

The camera clicks. They do not seem to mind

Involuntary immortality.

I change a reel, and spiral down to find
Them stomping through the flower-beds with glee. They say 'Ni hao', remembering their manners, They leap away through hollyhocks and cannas. (Seth [7] 12)

In the garden, the speaker and the boys seem to have a reciprocal agreement to amuse each other-"I pull fierce faces" and "spread my arms and grunt" to make the boys laugh, while they either imitate "a baby elephant" or flare and totter "like an owl" to give him "sudden delight."

This worldly pleasure Seth carefully sketches out is intrinsic to Suzhou classical gardens. In an effort to keep away from absolute solitude, to rephrase Ke's observations, the garden owners frequently invited their friends over, together engaging in boisterous and drunken merrymaking. What's more, their seeking for worldly pleasures may even find expression in the engraving patterns they preferred. One popular pattern, for instance, exhibits $\mathrm{Li}$ Bai, a much applauded poet of Tang Dynasty who took great delight in drinking.

The immensely enjoyable picture Seth paints in "The North Temple Tower," with the speaker at the center, may cast some light on his own quest for earthly pleasures. In addition to the words "delight" and "glee" that build up an overall totality of extreme joy and exaltation, the poem gives the following snapshot: so amused is the speaker by these two boys that he takes a picture to record the "involuntary immortality," which can serve as a striking metaphor for Seth's deliberate employment of the Shakespearean sonnet to immortalize, like what Shakespeare himself does in his sonneteering, the happy moments he had in Suzhou. In this intricately woven self-reflexivity lie his sincere hopes of recording, celebrating and perpetuating, like what he does in From Heaven Lake, the pure undisturbed pleasure he enjoyed in China.

Quite contrary to "delight" are worries and wishes, the other worldly pursuits that figure prominently in Seth's poems of classical gardens. His "The Tarrying Garden" is an illuminating example:

Here are no vistas. Piece by piece unfolds.

Stand by the rock. The lotus and the fish,

In still pale yellows, greens and fluid golds

Startle the rainy sky. Or if you wish

Stare at a single slab of cursive script

Sealed in the whitewash, passionate, bone-strong,

Crafted, uncrafted, singular, and stripped

Of all superfluous charm. Or walk along

The covered walks, the courtyards and the pools,

The zigzags of embodied hesitation,

A strict game where, within the given rules

You may throw dice or follow inclination.

The Tarrying Garden, piecemeal or entire:

Meander, tarry, amble, pause, admire. (Seth [7] 14)

A Shakespearean sonnet as well, "The Tarrying Garden," through the second-person point of view, brings into sharp focus a traveler's experience in the titular garden, where "you" either "Stare at a single slab of cursive script" or "walk 
along, The covered walks, the courtyards and the pools," overflowing, as it were, with ease and peace.

The sonnet, though full of life, is not an eyewitness account whatsoever, and "you," the author's poetic avatar, unleashes an outpouring of worries and wishes. To begin with, the "single slab of cursive script" "you" are examining is a stone inscription, where "rubbings of extraordinary calligraphic works, and the owners' gardening literature, authentic works of the celebrity letters (including emperors' handwriting)..." (Ke [3] 26) are supposed to be preserved. There exists, therefore, in the tourist's dedicated "staring" an undying preoccupation with the "superfluous charm," i.e. glories, fame, and riches represented by the inscription. The "zigzags of embodied hesitation" this tourist later bumps into carry further implications - given a garden life in tranquility, one's wishes and worries still reign supreme. The same holds true for Seth himself-although he lived and traveled undisturbed in China, the worries, either about his research or his family, could never be completely removed. He records, for instance, in From Heaven Lake: "Everyone who returns after an absence of a month to the place where he lives, knows, as he opens his mailbox, a uniquely bitter-sweet mixture of anticipation and apprehension. There is no letter from Stanford about my research, but then there are no unpaid bills either"'(Seth [6] 32).

Seth's worries and wishes dovetail nicely with the garden owners'. Never could the owners genuinely retire into silence and obscurity even after they moved into those havens of peace and serenity, and political ambitions and worries still remained in them. Ke [3] declares:

They probably lapsed into decay and decadence, a condition in which "The battle hero is long past his prime, And can go nowhere other than this land of warmth." However, most of them demonstrated an "unwillingness," "in two minds" in particular. The gardens, where "a punch measures around one hundred ren, and an instant's walk covers almost one thousand li ${ }^{\text {vi }}$, seem to facilitate their comfortable life in seclusion only, but in them lie the owners' secret wishes to "hold complete sovereignty over a certain field"(translation mine) (50-51).

In stark contrast to the garden flora and fauna, the tourists of Suzhou classical gardens serve as Seth's another vehicle of expression, vividly illuminating his worldly pursuits that contribute to his moderate reclusion. In the meantime, Seth sketches out the sociable side of reclusion Suzhou classical gardens attach equal importance to.

\section{Conclusions}

Basking in the silence as well as noise of Suzhou classical gardens, Vikram Seth seems to have found a perfect site of enunciation for his fervent hope of moderate reclusion-one can lead a seemingly contradictory, but nonetheless worthwhile life of both unworldly detachment and worldly pursuits. It is this poetic attempt that lends great vividness to the moderate reclusion intrinsic to the classical gardens in Suzhou. Taken together, Seth's poetic effusion and Suzhou classical gardens have made a perfect match.

\section{Acknowledgements}

This paper is supported by the National Social Science Fund of China (15CWW020) and the Social Science Fund of Jiangsu Province (14WWC001).

\section{REFERENCES}

[1] Mokashi-Punekar R. Vikram Seth: an introduction. New Delhi: Foundation Books; 2008.

[2] Mohanty S. A critical analysis of Vikram Seth's poetry and fiction. New Delhi: Atlantic Publishers \& Distributors Ltd; 2007.

[3] Ke J. Fun with Suzhou classical garden. Beijing: Cultural Relics Publishing House; 1994. (柯继承, 《苏州园林趣谈》, 北京: 文物出版社, 1994 年.)

[4] Wang Y, editor. Suzhou classical gardens. Shanghai: Shanghai Lexicographical Publishing House; 2003. (王萝编 著, 《苏州古典园林》, 上海: 上海辞书出版社, 2003 年).

[5] Seth V. Two lives. New Delhi: Viking; 2005.

[6] Seth V. From Heaven Lake: travels through Sinkiang and Tibet. New York: Vintage Books; 1987.

[7] Seth V. The Humble Administrator's Garden. Manchester: Carcanet Press Ltd; 1985.

[8] Seth V. Three Chinese poets: Wang Wei, Li Bai, and Du Fu. New York: Harper Perennial; 1992.

[9] China Suzhou Classical Garden Administration, editor. Suzhou classical gardens. Shanghai: Tongji University Press; 1991. (苏州园林管理局编著, 《苏州园林》，上海：同济 大学出版社, 1991 年.)

[10] Welch P. Chinese art: a guide to motifs and visual imagery. North Clarendon: Tuttle Publishing; 2008.

\section{Notes}

i In the interview "From China, With Love," for instance, the interviewer Sitanshi Talati-Parikh writes: "The reclusive writer Vikram Seth goes From Heaven Lake down memory lane

http://www.verveonline.com/72/life/vikram.shtml

ii In the poem "Moderate Reclusion," Bai Juyi (772-846), a Chinese poet of the Tang Dynasty, identifies three types of traditions of reclusion in China:

"Courts and markets facilitate great reclusion,

Hills and forests enable petty reclusion.

Deserted are hills and forests,

Noisy are courts and markets.

Better to live in moderate reclusion,

Like the remaining government officials in each department.

Both in power and in seclusion,

Neither busy nor idle...."

iii Wang Wei (701-761)'s literary influence on Seth is enormous. Roopali 
Gupta observes: "he stumbled upon the translated works of T'ang dynasty Chinese poet Wang Wei. Seth was so affected by these poems that he decided to learn Mandarin so that he could read the Chinese master in the original...he was writing poetry in Mandarin within a year." See Roopali Gupta, Vikram Seth's Art: An Appraisal, New Delhi: Atlantic Publishers \& Distributors Ltd, 2005, p. 2.

iv Chen Tiemin, for instance, maintains: "Throughout his life, Wang Wei retired into seclusion several times, and accordingly, most of his poems revolve around a sense of withdrawal. This thematic preoccupation still showed itself even when he was back in power." Chen Tiemin, Wang Wei Revisited, Beijing: Beijing Normal University Publishing Group, 1990, p. 124. (陈铁民, 《王维新论》, 北京: 北京师范学院出版社,1990 年,第 124 页.)

v This is a line from Li Bai’s “A Message to Meng Haorao.” Both Chinese poets of the Tang Dynasty, Li Bai and Meng Haoran developed a lifelong friendship.

vi Both ren (仞) and li (里), though no longer in wide use, served as major units of linear measurement in ancient China. 